WhO IS AfRAid OF WILLIAM

SHAKESPEARE? SHAKESPEARE

FOR YOUNG ADULTS
Brno Studies in English

Volume 47, No. 1, 2021

ISSN 0524-6881 | e-ISSN 1805-0867 https://doi.org/10.5817/BSE2021-1-11

\title{
IVONA MIŠTEROVÁ
}

\begin{abstract}
Works of classic literature have often attracted the attention of adaptors, particularly in the field of children and youth culture. Shakespeare's plays and sonnets are no exception. There have been both many Shakespeare adaptations intended for young people and studies on these adaptations. However, not much attention has been paid to Czech Shakespeare adaptations for children and young adults. This article explores the various ways young Czech adults can encounter Shakespeare's plays. It focuses primarily on Czech Shakespeare adaptations intended for children and young adults. It examines a range of reworkings such as abridged Czech versions, stage productions for teenagers and puppet performances which are (in some cases) discussed in the context of the British Shakespeare aimed at a juvenile audience.
\end{abstract}

\section{Key words}

William Shakespeare; children's literature; young adults; adaptation; puppetry; reception

\section{Introduction}

In her article written in connection with the Stratford Theatre Festival, Ontario, Canada, Corrie Shoemaker (2018) - a novelist, poet, playwright and Shakespeare scholar - argues that children can be exposed to Shakespeare at an early age and bolsters her argument with references to both neuroplasticity research findings and opinions of educators and theatre practitioners. Royal Shakespeare Company director Gregory Dorand ${ }^{1}$ makes a similar claim, declaring that even very young children can understand Shakespeare's plays and be influenced by them. "At it's [sic] best the work of Shakespeare, through the magic of storytelling, and the impact of deep truths, builds bridges into young peoples' imaginations." (Shoemaker 2018: n.p.). There are various theoretical and practical reasons for introducing Shakespeare to children and young adults, as well as many significant benefits to be gained from the presentation of Shakespeare's work to youngsters and monitoring their reception. In Great Britain, Shakespeare's work is a compulsory part of the National Curriculum, which confirms its supreme cultural value. ${ }^{2}$ Currently, there is an abundance of teaching resources, theoretical publications, journal articles and essays dealing with teaching Shakespeare (not only) to younger students. 


\section{Ivona Mišterová}

Rex Gibson's Teaching Shakespeare: A Handbook for Teachers (1998, 2011) explores active approaches to teaching Shakespeare and provides the reader with a number of practical examples and suggestions for classroom activities. It emphasizes learner-centred Shakespeare teaching, during which students actively participate in the meaning-making process and become agents of their own learning. The task for Shakespeare teachers, as formulated by Gibson, is echoed in a number of theoretical and practical publications: "The task for Shakespeare teachers is to make 'studying Shakespeare equate with enjoying Shakespeare"” (Gibson 2011: 25).

An anthology of thirteen essays entitled Teaching Shakespeare: Passing It On (2009), written by Shakespeare scholars and edited by G. B. Skip Shand, discusses a variety of approaches to teaching Shakespeare, such as performative teaching, literary analysis merging with theatrical reading and using filmic adaptations. Broadly speaking, it shares the Shakespeare experience. A similar format can be found in a collection of thirty-one essays, edited by Naomi J. Miller and published under the title Reimagining Shakespeare for Children and Young Adults in 2003. Written by Shakespeare scholars, teachers and authors of children's books, the essays share experiences with bringing Shakespeare to children of all age levels. In her introductory article, "'What's in a name?': Collaborating with Shakespeare at the Millennium", Miller captures and brings to the fore the significance of Shakespeare's work for youngsters: “(...) children and young adults represent a potential market for Shakespearean material, both through the school systems of Great Britain and the United States as well..." (Miller 2003: 2). In Miller's view, each new reimagining of Shakespeare is given a specific local habitation and a name through which Shakespeare is to be explored. It is not the particular form of the reimagining that matters, but rather the synergy of name, location and words, which compose the reinvented world of Shakespeare. An overlap between theatrical practice (arts pedagogy) and studying Shakespeare is discussed in Joe Winston's monograph Transforming the Teaching of Shakespeare with the Royal Shakespeare Company (2015). It provides insight into the work of the renowned British theatre company, which not only performs Shakespeare's plays but also offers an extensive Shakespeare education zone, and suggests how to connect the rehearsal room pedagogy with classroom practice to benefit both teachers and students. The essence of this approach lies in hearing and sensing the language, which unlocks the imagination and lets it affect readers: "Words should disturb, delight, and provoke the hearer, not merely make sense" (Barry in Winston 2015: 38). In Winston's view, the Learning and Performance Network (LPN), the first long-term partnership programme between schools and theatres established in 2006, helps to improve students' attitudes towards both Shakespeare and school. The idea of active learning and theatre-based classroom pedagogy (drama-based pedagogy) is also central in Ayanna Thompson and Laura Turchi's book Teaching Shakespeare with Purpose: A Student-Centred Approach (2016), which is designed primarily for secondary school teachers. It shows various ways for engaging students with Shakespeare in the $21^{\text {st }}$ century.

Sarah Olive's Shakespeare Valued (2015) offers an overview of Shakespeare education policy and pedagogy by addressing the key questions of how Shakespeare 
is "constructed in the documents and created by governments and educators, writing for and working in schools, theatre education departments and heritage organisations" (2015: 3). Particular chapters of the book concern the notion of value in different domains relating to Shakespeare and education (i.e. education policy, pedagogy, heritage and theatre education departments) between the years 1989, when the National Curriculum for English was introduced in the United Kingdom and Shakespeare became the only compulsory author, and 2009. The English curriculum is the focus of attention in Liam E. Semler's Teaching Shakespeare and Marlowe: Learning Versus the System (2013). As the title indicates, the book explores what it means to teach Shakespeare "in a world where educational institutions are increasingly driven by formal procedures" (2013: 1). Although Semler refers to the senior-secondary English curriculum in New South Wales, his questions open up space for reflecting on and implementing innovative approaches to teaching Shakespeare within formal educational systems. The questions of why and how to teach Shakespeare are revived and rethought in a recent collection of 17 essays edited by Sidney Homan and entitled How and Why We Teach Shakespeare (2019), which draws upon the personal experiences of the contributors.

Theoretical concepts of and practical approaches to teaching Shakespeare obviously extend beyond geographical and virtual borders and have been explored and assessed by a wide array of international scholars and practitioners with a focus on various issues such as national traditions of studying Shakespeare and the influence of Shakespeare on shaping the way Shakespeare is taught, explored and performed. Based on a survey carried out by Peter Cochran, Shakespeare is part of the national curriculum in 65 per cent of countries and is studied in secondary schools by a majority of students in, for instance, Australia, Azerbaijan, the Czech Republic, Denmark, Hungary, Poland, India, South Africa, Sudan, Vietnam and many others (2013: 2). Many international teachers and scholars thus deal with teaching Shakespeare to foreign language students. Speaking of Central European countries, for instance, a history of teaching Shakespeare in both East and West Germany has been considered by Ruth Freifrau von Ledebur (in Bezzola Lambert and Engler 2004).

In the contemporary Czech Shakespeare portfolio, teaching resources are still rather scarce compared to quality translations and scholarly publications. Nevertheless, some useful ready-made Shakespeare materials are provided by the Methodology Portal of the Framework Educational Programme, the Association of Czech language teachers and by a portal intended for specialist schools offering inclusive education for children whose mother tongue is not Czech. ${ }^{3}$ Shakespeare is also taught as part of the curriculum in primary and secondary schools (not to speak of university education). Shakespeare is listed among the significant theatre personalities in the Educational Programme for the first level of primary schools (Educational Programme for Primary Schools 2009: 145) and is also included in a literature curriculum for the second level.

Living in a digital age, web sites and online resources are easily accessible. Several web sites - or rather, web portals - allow remote users to access a wide range of Shakespeare resources such as The Shakespeare Project, which was founded 


\section{Ivona Mišterová}

in 2019 by Peter Basham, an actor and manager, and Laurence Taylor, an executive producer. Among other activities, it delivers workshops on the texts of Shakespeare's plays, organizes seminars on productions and provides in-school workshops. ${ }^{4}$ It should not pass without mention that the world's largest collection of the printed works of William Shakespeare is stored in the Folger Library, an independent research library in Washington, D.C., whose web pages include a section called TeachELearn, which provides visitors with helpful classroom resources, teaching modules and a series of podcasts. ${ }^{5}$

Advanced information and communication technologies are obviously opening up new possibilities for the engagement of young learners with Shakespeare using methods and approaches which are most understandable to them. Consequently, it is perhaps not so surprising that, among other genres and media, Shakespeare's plays have inspired PC game developers and have entered the 3D virtual world (for more information on PC games, see Hostýnek 2018: 91-100). At the end of 2007, the eagerly anticipated multiplayer online role-playing game Arden: The World of William Shakespeare was released. It takes place in the virtual city of Ilminster, where the players' online characters (avatars) interact with characters from Shakespeare's plays, complete assigned tasks and answer trivia questions to improve their scores. In Romeo: Wherefore Art Thou? (2009), players assume the avatar of Romeo, with whom they can navigate through ten levels of Shakespeare Country collecting roses and chapters from Shakespeare's plays while avoiding various dangers. Through a modification of The Typing of the Dead: Overkill, Shakespeare has also entered the world of horror. In this game, which fuses elements of horror and (black) comedy, players shoot zombies by entering words and sentences from Shakespeare's works. In contrast to the Shakespeare versus zombie combat, the literacy arcade game 'Speare (2007) combines elements of an arcade game with educational purposes. The goal of the game, intended for youngsters aged 10-15, is to complete a mission by recovering stolen knowledge that is, words, phrases and facts which draw upon Shakespeare's plays, particularly Romeo and Juliet (Mišterová 2019: 46-47). The game thus intends to strengthen communication and literacy rather than focus on violence and destruction.

Apparently, Shakespeare is not only, as Ladina Bezzola Lambert and Balz Engler (2004: 13) perceive him, a border-crosser, but also a "macro influencer" or a "thought leader", as contemporary young adults might call him. As aptly summarized by Paul Prescott, "Shakespeare is everywhere in [not only] contemporary culture. His presence is not confined to the 'official' locations of classrooms, universities and theatres, but permeates popular mass media such as cinema, television, tabloid journalism, computer games, pop music, comics and advertisements" (2010: 269). Indeed, Shakespeare and his work have been explored and approached from various points of view; ${ }^{6}$ however, not much attention has been paid to Czech Shakespeare for adolescents. This article explores various ways through which young Czech adults encounter Shakespeare's plays. It examines a range of Shakespeare's works intended for adolescents such as Czech Shakespeare abridged versions, stage productions for teenagers and puppetry, which are (in some cases) discussed in the context of the British Shakespeare aimed at a juvenile audience. 


\section{Abridged Versions Intended for Adolescent Readers}

The end of the $20^{\text {th }}$ century and the beginning of the $21^{\text {st }}$ century have seen an explosion of Shakespeare storybooks for children and young adults in Great Britain and the United States. It seems to have been a positive trend, which indicates both a constant interest in Shakespeare (at least from the side of adaptors) and a constant effort to engage young audiences with Shakespeare. A discussion of the issue of reworking (which here also includes rewriting, adapting and appropriating) of canonical texts for (not only) young adults includes various concepts and theories concerning the relationship between hypotext and hypertext (leaving aside Julia Kristeva's terms genotext and phenotext), intertextual significance, recontextualization of narrative and characters, aesthetic motifs and criteria, among other aspects. Adaptations for young recipients can be characterized in terms of, for example, the age of the target readership, which should take into account their literacy skills and mental and aesthetic capacity (children, young adults); purpose of the adaptation (educational, entertaining or a combination of both); transformation of genre (abridged/re-written plays, prose fiction including graphic novels and poems); ${ }^{6}$ and the extent to which the adaptation incorporates the original (e.g. a free/faithful adaptation, transcription, imitation). Adapting Shakespeare's work for young readers carries its own problems. From a theoretical point of view, there a comprehensible definition of adaptation (of canonical texts for young readers) is lacking, or rather there are various perspectives taken by scholars, adaptors and educators. Practically speaking, adaptations can be seen as low-valued (and unnecessary) interpretations of existing valuable works. As Anja Müller argues in her introduction to Adapting Canonical Texts in Children's Literature, "Fears of 'downsizing', 'dumbing down', oversimplifying, bowdlerizing or only abridging venerable canonical artefacts still inform the evaluations. Even if the adaptation itself is appreciated, the underlying hope seems to be to drive the young reader home, that is to the original, which alone can guarantee full aesthetic enjoyment" (Müller 2013: 2). One question, however, might be whether a homecoming - that is, guiding young readers to an original version - is primarily intended and desired by adaptors remaking stories for children and young adults, who may not be prepared for the vividness of Shakespeare's original language, complexity of thoughts and plot, and colourfulness of characters.

As already mentioned, a number of Shakespeare adaptations emerged at the turn of the $21^{\text {st }}$ century. Transforming Shakespeare's works to suit various genres, adaptors have created a large base of reworkings, ranging from more or less traditional folktales to radical cut-down versions, some of which may even be suspected of undermining or, at least, unsettling the canonical status of the original. Edith Nesbit's collections of sensitively written and imaginative tales Twenty Beautiful Stories from Shakespeare (1907) falls into the first category. Although it was originally published in 1907 (as an expanded version of The Children's Shakespeare, 1897), her works have been reedited and published in the $21^{\text {st }}$ century. The fairy tale characters and plots are in some cases underlined by a traditional opening pattern "Once upon a time" and the hope or reconciliation expressed at the end. Moreover, they show the author's understanding of a child's mentality 


\section{Ivona Mišterová}

and interpretative skills. As Iona Opie, a British specialist on childhood culture observes in her introduction to The Best of Shakespeare, "E. Nesbit has rehabilitated the plays as pure entertainment. She tells the stories with clarity and gusto, guiding the reader through the twist and turns of the plot, and giving the flavour of each play by the skilful use of short quotations" (in Nesbit 1997: 7). Shakespeare adaptations for children and young adults, retold by Terry Deary, the British children's writer, known for his Horrible Histories series, are another kind of Shakespeare rendition intended for pre-teens. His collection Top Ten Shakespeare Stories (1999), illustrated by Michael Tickner, provides the reader with insight into ten plays, including six tragedies (King Lear, The Merchant of Venice, Romeo and Juliet, Macbeth, Hamlet and Julius Caesar, which can also be perceived as a history play), three comedies (A Midsummer Night's Dream, Twelfth Night, The Taming of the Shrew) and a romance (The Tempest). ${ }^{7}$ The value of the book lies not only in Deary's refreshing retellings of the plays but also in his use of various genres and bonus materials, such as top facts accompanying each tale, which encourage understanding of both the tale and its context and motivate further reading. It is probably not surprising that the collection has been reprinted several times and particular tales have also been published individually.

No less important than the text is the way in which visual images contribute to understanding the text. An essential role in the process of reception is thus played by the illustrations which complement the story. In her picture book Bravo, Mr William Shakespeare! (2009), British writer and illustrator Marcia Williams translated seven of Shakespeare's plays into a cartoon strip format, reflecting the interconnection between the textual and the visual. Her tales are characterized by the use of bright colours and caricatures, thereby resembling an animated film. In addition to coloured pictures, there are three layers of language. First, short quotes from Shakespeare are written directly into the pictures; second, captions in modern English, which describe a given scene, are placed beneath the pictures; and, third, each page is surrounded by an artistically decorated border, showing various period audience members, including Shakespeare himself, responding to the performance or rather commenting on it. Williams's comic strip thus resembles a theatrical performance, which, in fact, it chronicles visually.

Graphic novels such as Macbeth (2008), Romeo and Juliet (2011), Julius Caesar (2013) and Hamlet (2020) may be seen as a follow-up approach from a distinctive visual perspective, which encourages young readers to discover the interplay between meaning and form, and establishes a connection between printed text and visual patterns. In contrast to Williams's comic strip, the text is written in traditional speech bubbles without additional explanatory notes. A new scene is indicated with an illustration on an old beige parchment with numbered acts and scenes, which helps young readers to orientate themselves in the play. As Shannon R. Mortimore-Smith observes (2012: 84), "Reading Shakespeare through graphic novels and manga (Japanese comics), allows students the opportunity to engage in a type of reading that more closely emulates performance itself." The interpretation of such texts is thus based not only on the decoding of meaning (through the written hints), but also relies on facial expressions, and body language to describe each character. 
Another attempt at radically shortening and simplifying canonical works of world literature is Alexander Aciman and Emmett Rensin's Twitterature (2009), which includes, beside other works, five Shakespeare plays retold in tweets: Macbeth (@BigMAC), Hamlet (@OedipusGothplex), Romeo and Juliet (@DefNotAHomeo,@JulieBaby) and The Tempest (@Lolspero). According to the authors, the intention behind this unusual and comic rendition of literary classics is to liberate the characters from the constraints of the times of their origin and make them "happening youngsters" (Aciman and Rensin 2009: xv). Each story is retold in no more than twenty tweets and each tweet contains a maximum of 140 characters. The language style of the tweets is understandable, reflecting everyday spoken conversation (with sporadic inserted taboo words) and adding more intimacy to particular tweets. A number of abbreviations and modern expressions are included in the appendix, which serves as a guide to the reader not acquainted with such neologisms as bromance, ana (anorexia), mia (bulimia) and bug, (transformation in the sense of Kafka's Gregor Samsa). An example of a contemporary Shakespearean adaptation, which deploys the text message language often used by young adults, is a new series entitled OMG Shakespeare, which was written by New York children's book editors Courtney Carbone and Brett Wright and released in 2016. The series consists of four Shakespearean remixes: YOLO Juliet (Brett Wright), srsly Hamlet (Courtney Carbone), Macbeth \#killingit (Courtney Carbone) and A Midsummer Night \#nofilter (Brett Wright), which retell Shakespeare's plays through text messages, emoticons, smileys, Facebook updates and Instagram hashtags, thereby combining a traditional literary genre with the digital world (Mišterová 2019: 48).

The process of adaptation is not a simple task, and the success of an adaptation cannot be guaranteed, but is only to a certain degree affected by the adaptors' decisions about what to leave out and what to keep in the text, which might be difficult and misleading. Indeed, Abigail Rokison (2013: 7) points out that a focus on the moral values and didactic potential of Shakespeare's plays, prevalent in the past, changed into an emphasis on the entertainment value and theatricality of plays. The moralizing and didactic aspects typical of the past are well illustrated in Charles and Mary Lamb's storybook Tales from Shakespeare (1807). In Pericles, the title character's beautiful daughter, Marina, who is originally sold into prostitution by pirates, is turned into a slave who earns money for her master using her skills and soon becomes famous for her erudition and dexterity.

The pirate who had made Marina his prize carried her to Mitylene, and sold her for a slave, where, though in that humble condition, Marina soon became known throughout the whole city of Mitylene for her beauty and virtues; and the person to whom she was sold became rich by the money she earned him. She taught music, dancing, and fine needleworks, and the money she got by her scholars she gave to her master and mistress... (Lamb 2013: 351)

However, this still leaves the question of how readers who read the tale first will react to Shakespeare's play and its integrity, and how they will observe the moral 


\section{Ivona Mišterová}

and emotional issues involved in the text. In this case, the plot and themes are obviously simplified, and the character of Marina is trivialized, sentimentalized and given the impression of a hard-working virtuous woman. ${ }^{8}$

A similar, though not identical approach can be found in the Czech storybooks Tales from Shakespeare I (Příběhy ze Shakespeara I, 1996) and Tales from Shakespeare II (Př́íběhy ze Shakespeara II, 1997), written by Czech writer, editor and scriptwriter Vladimír Hulpach, ${ }^{9}$ whose literary work is devoted to retelling myths, legends, songs and stories from the whole world. His extensive work includes, for example, Native American Stories (Indiánské příběhy, 1987), King Arthur and his Knights (Rytíri krále Artuše, 1992), Once upon a Time: Fairy Tales from around the Whole World (Bylo nebylo: Pohádky z celého světa, 2007), Stories of Don Quixote (Příběhy Dona Quijota, 2019) and many others. In his Shakespeare collections, Hulpach introduces 18 of Shakespeare's plays, remade into prose fairy tale-like narratives aimed at young Czech readers. His approach endorses the knowledge of a fairy tale language, an insight into plot and characters and an understanding of the needs of the target readership. Both books are illustrated by Karel Toman, a Czech painter, graphic artist and illustrator. The first book comprises mostly well-known tragedies (Timon of Athens, Antony and Cleopatra, King Lear, Macbeth, Romeo and Juliet, The Merchant of Venice, Hamlet, Othello and King Richard III), three comedies (A Midsummer Night's Dream, The Merry Wives of Windsor and Twelfth Night) and a historical play (King Henry IV). Although the reader is not given any explanation for the selection of plays or the order of the adapted tales, it is conceivable that they represent a span of Shakespeare's writing career and the diversity of themes and forms he made use of. The overall layout of the books uses neither chronological ordering nor thematic organization, but most probably focuses on content-based choices and comprehensibility.

Concerning the above-mentioned play Pericles, which is included in the second volume, Hulpach also turns Marina into a slave, but omits any details concerning her duties or master and immediately makes her Lysimachus's wife:

True, they [the pirates] did not care about her life, of course, but the moment they saw her beauty, they got another, no less criminal idea: to sell her into slavery. They sailed with her up to the island of Lesbos and the town of Mytiléne [sic] and sold her there in a market like every ordinary slave girl. However, this time, fortune finally smiled upon Marína [sic]: the ruler of the island himself, Lysimachus, redeemed her from slavery, and after some time, when he got to know her strange events and her royal origin, he proposed to her. ${ }^{10}$ (Hulpach 1997: 41-42)

The latest Czech Shakespeare adaptation intended for middle school children appeared in 2016 as the first volume in the series on The Greatest Playwrights. Twelve of Shakespeare's plays are retold and illustrated by renowned author and illustrator Renáta Fučíková. ${ }^{11}$ Each of the chronologically organized tales is supplemented with an introduction and conclusion, which shed light on the distinctive features of the Elizabethan and early Jacobean period such as fashion, architecture, family life, education, health and illnesses, overseas expeditions, warfare, 
conspiracies, witch hunts and the life stories of British monarchs and their relatives. Each tale contains a significant monologue or dialogue from Shakespeare's play in Jiř́ Josek's translation. Altogether, the collection provides the reader with a selection of well-known comedies (The Taming of the Shrew, A Midsummer Night's Dream, Much Ado About Nothing, As You Like It and Twelfth Night), tragedies (Romeo and Juliet, The Merchant of Venice, Hamlet, Othello, Macbeth and King Lear) and a romance (The Tempest). In the author's words, the book does not aspire to answer unanswered questions about Shakespeare's life and authorship but "presents a picture of the time of the late European Renaissance and pays tribute to the most famous playwright of all time" (Fučíková 2016: 8). For those who prefer listening to reading, the book was published as an audiobook in MP3 format in 2017. Particular tales are smoothly and sensitively narrated by professional voice actors and actresses, ${ }^{12}$ which allows listeners to immerse themselves in the plot and visualize the stories in their minds. The print book and audiobook are directly related and carry almost the same content, but each possesses its strong and weak points. Whereas the print book includes a large number of stimulating illustrations, which themselves often seem to contain miniature subplots, the audiobook takes advantage of the strong language content which is spoken aloud. However, the value of the book lies in Renáta Fučíková's brown and white Verist drawings, through which she expresses the meanings underlying the retold tales. For art critic Radim Kopáč, Fučíková's work is marked with humility and artistic discipline. He observes that she "does not draw attention primarily to the visual language, she does not want to overwhelm the viewer's [recipient's] eyes but she focuses on the message and that is the reason why her work exceeds the usual borders of book illustration"13 (Kopáč 2019: n.p.).

\section{Stage Productions for Teenagers}

Like a picture book adaptation, a stage production of a Shakespeare play offers insight into the original work. The first Czech professional theatre for children was established by actress and stage director Míla Mellanová in 1935 in Prague on the model of Natalia Satsova's Moscow Theatre for Young Audiences. After World War II, three new theatres for children arose in Prague, Brno and Ostrava, which performed only for schools (Čeporanová 2014: 211). From the 1960s on, several theatre companies specializing in young audiences have come into existence. ${ }^{14}$ Moreover, traditional theatres occasionally produce performances for young adults such as the Pocket Theatre in Prague (Kapesní divadlo). Productions consist mainly of well-known Czech fairy tales and classic works of world literature. Among recent Shakespearean contributions ranks Romeo and Juliet, staged by the Gong Theatre in Prague in 2019. The director, Janek Lesák, left only the basic skeleton of Shakespeare's play, changed the verse into prose, and reduced the cast to two actors who embody all the characters of the play. A different example of a Shakespeare adaptation is an educational programme entitled How did you mean it, Mr Shakespeare? Or, The Life and Work of the Greatest Playwright (Jak jste to myslel, pane Shakespeare? Aneb Život a dílo největšího dramatika) 
which was launched by the Little Theatre for Schools Hradec Králové (Divadélko pro školy Hradec Králové) on the $450^{\text {th }}$ anniversary of Shakespeare's birth in 2014. It is not a performance in the traditional sense of the word, but rather a lesson about Shakespeare's life and work. Explication is supplemented with short “teasers" from the plays Richard III, Love's Labour's Lost and Romeo and Juliet, as well as the Sonnets. According to producers, the performance is intended for both primary and secondary school students and can be adjusted to fit the needs of the recipients. ${ }^{15}$

A cabaret-like performance that combines entertainment and education emerged in the repertoire of the independent theatre Tramtarie (Divadlo Tramtarie) in Olomouc in 2015 under the title The Naked Shakespeare Cabaret: Five in One or Five Most Famous Tragedies of William Shakespeare in one Theatrical Comedy (Kabaret Nahatý Shakespeare: Pět v jednom aneb Pět nejslavnějších tragedií Williama Shakespeara v jedné divadelní komedii). It promised to answer everything spectators wanted to know about Shakespeare but were afraid to ask. The director, Jiří Trnka, commented on his attempt to attract, entertain and educate secondary school students as follows: "In the form of cabaret, we lighten dark stories full of murder, mysticism and tragic love. The combination of cabaret, including original songs, together with original famous scenes and monologues from Shakespeare's tragedies create together an extremely lively theatrical form" (2019, n.p.). ${ }^{16}$

A distinctive example of a Shakespearean reworking for adolescents is Hamleteen, whose premiere took place in February 2012 at the Alfa Theatre in Pilsen. As the title indicates, greater emphasis is placed on Hamlet's uneasy adolescence and his search for identity than on his quest for justice and revenge. The most striking difference between the original play and the adaptation is the way in which Hamlet searches for his identity and identifies himself as a member of various subcultures such as Scouting, punk and emo. The adaptation underscores the private dimension of the classic story and provides the audience with insight into adolescents' inner world including feelings, struggles, perceptions and wishes.

The production is characterized by a number of innovative elements. The tragedy is transformed into a musical farce, embedded in the present and imbued with sarcasm. There is often black humour in the parallels and consonances with Shakespeare's play. This purely Czech adaptation compresses Shakespeare's longest and perhaps most notorious play into three stages, each representing a different subcultural identity. In this new Shakespeare paradigm, the old Hamlet is an enthusiastic Scoutmaster, who has transformed the Danish Kingdom into a Scout camp, subject to strict military discipline, including regular morning exercises, earning badges (called little "beavers"), cleaning tents and grounds and wearing Scout uniforms with pride every day (Mišterová 2013a: 70). Not everyone is happy with the status quo, of course, particularly Claudius, who tends to resist authority. His rebelliousness results in the improper completion of his assigned tasks and subsequent deduction of points. Although he tries to bottle up his feelings of anger, this affects his relationship with his brother, and finally reaches a boiling point. He airs his frustration and wrath towards old Hamlet, of whom he is, moreover, jealous. However, despite his uncouth behaviour and 
not particularly pleasing appearance, Gertrude is attracted more to him than to her husband, who shows no interest in their marriage. Scouting, not his wife, has the elder Hamlet's full attention. Gertrude feels neglected and trapped. Her hasty second marriage is thus more understandable given that she was unhappy and wanted to enjoy life. Also, other Shakespearean characters assume different statuses. Laertes is a homosexual, who is unhappily in love with Hamlet. Before he goes West, he warns his sister against Hamlet's immaturity and egoism. Soon afterwards, he returns home, however, transformed into the Dead Man. Hamlet's childhood friends, Rosencrantz and Guildenstern, resemble debauched boozers, and Polonius is the manager of a disreputable house. Ophelia looks like an energetic girl for whom chocolate acts as an instant antidepressant, helping her to feel better.

The main focus of the performance is adolescence. It tells the story of a youngster who tries to cope first with his father's passion for Scouting, and then with his death. Hamlet's initial identification with Scouting is motivated and supported by his father. In this sense, the old Hamlet embodies authority and moral principles to be followed. For the young Hamlet, earning a merit badge, which he proudly wears on his uniform, is the highlight of his Scouting experience. His subsequent punk and emo interludes underline the intense emotional distress and alienation he experiences after the death of his father. Yet, he refuses any offers of help and comfort from others who fear for his sanity. However, his suffering is not in vain. He finally realizes that even his father was not perfect and had weak spots. It is exactly at the moment he attains maturity that he comes to understand the truth about his father's death (and his fallibility) and his mother's happiness in her new marriage. Accepting the truth requires, no doubt, great personal courage. If Hamlet is able to accept the truth about his parents and himself, then he is able to step into adulthood. Cured of his idealism (Scouting), rebellion against conventions and a new family structure (punk) and extreme sensitivity and introversion (emo), he has found the raison d'être for his life and his true identity (Mišterová 2013a: 72-73).

\section{Czech Shakespeare Puppetry}

Given a well-established tradition of Czech puppet theatre, it is probably not surprising that the Czech puppet Shakespeare has also had a long and rich theatrical history, whose roots go back to the $18^{\text {th }}$ century when travelling troupes of puppeteers roamed the country and exhibited their shows (Drábek and Katritzky 2016: 1527-1533). ${ }^{17}$ Shakespearean puppet performances still enjoy considerable popularity today. Indeed, a number of puppet shows were mounted during the golden age of Czech puppetry in the $1980 \mathrm{~s}$ and at the turn of the $21^{\text {st }}$ century (Malíková 2016: n.p.).

One of remarkable productions of the late 1980s that deserves a mention was King Llyr, which premiered at the Alfa Theatre (Divadlo Alfa) in Pilsen in 1989. It was directed by Karel Makonj, using Milan Lukeš's translation. The director based his performance on the similarity between the world of people and an 


\section{Ivona Mišterová}

archetypal world of animals. The negative figures were characterized by distinctive animal attributes. For instance, the feet of the puppets embodying bad character traits had claws, and Lear's older daughters Goneril and Regan had their human heads replaced with crocodile and snake heads. This transformation clearly shows the association of people with animals and animal behaviour, which in this case captures undesirable predatory behaviour and carries a negative connotation. The atmosphere of old myths combined with the visual, animalistic metaphor was underscored by the ballad about King Lear, which heightened the emotional impact of the performance (Mišterová 2013b: 173).

Josef Krofta, known for his creative performances at the DRAK Theatre in Hradec Králové, interspersed modern Czech puppetry with the traditional Japanese theatre Bunraku in his performance A Plague on Both Your Houses! (Mor na ty vase rody!, 2001), in which the Japan Foundation and Japanese actors took part. In this new paradigm, the Italian city of Verona became a mysterious Asian city, in which Romeo and Juliet (the only puppets in the performance) found both love and death. The authenticity of the distant Asian location and the atmospheric tension were underscored by the use of dramatic drums placed on both sides of the stage, long poles used in martial arts, face masks, large fans and huge ruff collars. The performance conveyed a strong anti-war message against aggression from the ambitious and hostile world of adults.

In 2004, Jiří Vyšohlíd made another attempt to engage young audiences with Shakespeare through his production of Hamlet staged in the translation by Martin Hilský. The director cut the text considerably and removed many details and some characters, such as Rosencrantz and Guildenstern, so the performance lasted only 70 minutes (Malíková 2016: n.p.). All of the puppets - including marionettes, wayangs, Asian-inspired puppets and hand puppets - were precisely made. The visual image of Hamlet was further heightened by his glowing eyes and unruly hair, which stuck up on his head during tense moments. However, pandering to the young audience's taste resulted in chaotic arrangement and shortening of some scenes (the gravediggers' scene and Hamlet's scenes with the players who were represented by small unimpressive marionettes). One year later, Michal Dočekal, the current artistic chief of Prague City Theatres, demonstrated his skill in The Tempest, which he staged at the Naive Theatre of Liberec (Naivní divadlo Liberec) as guest director. He prioritized the play's visual side and its magical and fantastical elements. The visual aspects of the puppets thus became of special importance. Prospero's face mask, which looked like that of Shakespeare, both paid tribute to the playwright himself and underscored Prospero's supernatural power over others on the island. The fantastic set was composed mainly of modern materials such as plastic, Plexiglas and metal. An underpinning theme of magic was emphasized by harsh, cold lighting. Despite impressive visual effects (fiery feathers on Ariel's wings and a staff figure of Ferdinand, who had yet to obtain his human form), young audiences might have had difficulty understanding the details of the performance.

Shakespeare, or more precisely Macbeth (2005), appealed to the director of the Lantern Theatre (Divadlo Lampion) in Kladno, Karel Brožek, in whose performance, subtitled Witches Frolic (Rej čarodějnic), puppets appeared alongside 
six actresses and two actors. As the subtitle suggests, witches (each of them embodying Lady Macbeth in parallel) became the focal point for the performance. This somewhat provocative and multiple doubling offered the director an opportunity to provide Lady Macbeth with a kind of psychological (or mysterious) backstory, emphasizing her insanity and loneliness. The scenographer's (Alois Tománek) set, comprised of the ruins of a theatre bombed out during an unspecified war, resonated with the never-ending story of needless sacrifice and its fatal consequences. According to critical commentary, the aesthetic impact of Brožek's conception of the play was heightened by engaging music from the Slovenian avant-garde music group Laibach and a live drone performance by Petr Litvík on the didgeridoo (Soprová 2005: n.p.).

\section{Conclusion}

The end of the $20^{\text {th }}$ century and the beginning of the $21^{\text {st }}$ century saw both a continuity and transformation in Shakespeare adaptations intended for young recipients. They range from faithful adaptations relying closely on the plays to lose reworkings keeping only the main themes, which, in extreme cases, may not even be recognizable as Shakespearean. They include prose narratives, comic books, poems, (micro)blogs, computer games, theatrical adaptations, puppet performances, musical adaptations and film scripts. They may be adapted, amended, cut and completely reworked. Despite genre differences and a large number of remakes, they all intend to introduce Shakespeare to young audiences and suit their taste. The objective of this article was to show how Shakespeare's plays were adapted in the Czech Republic (and partly in Great Britain) to attract young audiences and to provide a brief overview of works aimed at children and youth.

First, the teaching of Shakespeare was of concern. Shakespeare has a firm position in education. Not only in Great Britain (England and Wales) was Shakespeare made compulsory in the National Curriculum for English in secondary schools, but as previously mentioned, 65 per cent of countries list Shakespeare in their secondary school curricula. According to a survey carried out by the Royal Shakespeare Company in 2012, 50 per cent of school children around the world study Shakespeare, albeit to different extents (Prescott 2015: 10-11). The inclusion of Shakespeare in national curricula needs no justification. It is reinforced by its literary heritage and cultural capital status. It is thus not surprising that there is an abundance of particularly English materials for teaching Shakespeare, including various approaches and classroom strategies. In the Czech Republic, schoolchildren encounter Shakespeare through Czech translations of plays and the Sonnets, or to be more precise, through extracts of such, which are contextualized within a broader framework of the European Renaissance and the development of the theatre. The content and teaching methods depend on a number of factors, such as the input and output requirements of the curriculum, teaching skills, the teacher's awareness with the topic and pupils' abilities. However, the efforts to make teaching and learning more engaging by using additional (mainly English) teaching resources, taking children to the theatre and watching films 


\section{Ivona Mišterová}

can be observed. In contrast to the Anglophone tradition of drama-based pedagogy, in the Czech Republic, drama-based pedagogy had been established as an independent field of study by the late 1990s, when foreign language teachers started to take notice and make use of it. Although drama-in-education is not yet a frequently used method of exposing children to Shakespeare, it should be integrated into teaching because it helps to develop a learner-centred approach and further encourages cooperation between schools and theatres.

As mentioned earlier, juvenile readers also become familiar with Shakespeare through abridged and retold versions of plays, in which the previously emphasized moral dimensions are being gradually replaced with more entertaining aspects. In contrast to the wide array of British Shakespeare adaptations for children, there emerged only two children's adaptations in the Czech Republic, by Vladimír Hulpach $(1996,1997)$ and Renáta Fučíková (2016, 2017). Hulpach retold the best-known plays under the title Tales from Shakespeare, and 20 years later, Renáta Fučíková rendered 12 plays in a historical setting. Both authors showed their ability to tell the basic plots of Shakespeare's plays in a realistic manner without including unnecessary details. Readable narratives are supplemented with significant monologues and dialogues from the plays in Czech translation, illustrations and historical facts and cultural facets of the Elizabethan Era. Though idiosyncratic in execution, Karel Toman's and Renáta Fučíková's illustrations stir the readers' imagination, develop their perceptual skills and help to create meaning. Altogether, both books help to engage schoolchildren with "the world of Shakespeare" and motivate them to read.

Another way children and youngsters encounter Shakespeare is through theatre performances, with live actors, puppets or those joining live actors with puppets. Throughout the Czech Republic, Shakespeare's plays have held a prominent place in the modern dramatic puppet repertoire, which ranges from more or less faithful adaptations retaining the basic plotlines and characters such as King Llyr (Alfa Theatre in Pilsen, 1989), The Tempest (Naive Theatre Liberec, 2002) and Hamlet (DRAK Theatre in Hradec Králové, 2004) to more radical productions employing exotic setting and figures such as A Plague on Both Your Houses!, staged in 2001 with Japanese participation, and Macbeth (2005), performed by the Lantern Theatre in Kladno, in which six actresses combined the roles of Lady Macbeth and witches. Reaching a teenage audience, Hamleteen (Alfa Theatre, 2012) depicts the young Hamlet's journey through adolescence to self-acceptance by his self-identification with subcultures like Scouting, punk and emo. Hamlet's temporary belonging to these subcultures can be conceived of as a call for intergenerational and interpersonal understanding and a search for constant values in an uncertain world.

As seen through the lens of a basic algebra, Czech Shakespeare textual adaptations embody constants, whereas theatrical adaptations symbolize variables. The difference between them lies in a particular rendition of the source material. Though falling into cross-generic adaptations, Czech retold tales for young readers do not significantly alter the source text like their Anglophone peers do by employing SMS text messaging and tweets. Nevertheless, faithfulness to the original does not diminish their value and popularity. They intend to introduce 
Shakespeare's work to children in an understandable way, while retaining its status as a cultural artefact and creating a sense of the past. In contrast to retold stories, performances for children let Shakespeare's past speak for the present and treat the original more freely: they redistribute characters' lines, use exotic settings and multiply characters, thereby creating resonances with contemporary (not only Anglophone) theatrical practices.

Going back to the question posed by the title of the article, the answer is, de facto, a double entendre: neither Czech children nor adaptors seem to be afraid of Shakespeare. Using different approaches towards the original, adaptors intend to give young audiences the chance to meet and experience Shakespeare through a young person's lens. Introducing Shakespeare to children and young adults is an ongoing task, because the playwright and his work should be (will hopefully be) a significant part of young people's culture and their "mental gear".

\section{Acknowledgements}

This research was conducted as part of the VF4 Project (No. 21920060) Shakespeare in Central Europe after 1989: Common heritage and regional identity.

\section{Notes}

1 Gregory Dorand is a British director and actor known for his significant theatrical Shakespearean contributions.

2 By the year 1991, Shakespeare's work was an important part of the Standard Assessment Tests (SATs) which are taken by students at the end of their third year in secondary school.

3 The links mentioned below include references to

(a) support materials for grammar schools:

https:/ / digifolio.rvp.cz/view/artefact.php?artefact=14919\&view=2905\&block=14543 (b) teaching materials prepared by Michaela Jiroutová and Radka Nevosadová for inclusive education:

https://www.inkluzivniskola.cz/sites/default/files/uploaded/cjl_w._shakespeare. docx

(c) the British Council's project English Page: Shakespeare Lives (2016):

https://www.britishcouncil.cz/projekty/vzdelavani/english-page-metro/shakespeare For more information, see The Shakespeare Project: https://www. theshakespeareproject.co.uk/

5 For more information, please see The Folger Library, “Teach\&Learn” section: https://www.folger.edu/teach-learn

$6 \quad$ Film and TV adaptations, PC games, etc. For more information on operas based on the plays of William Shakespeare, particularly Verdi's Otello, see Havlíčková Kysová 2016: 29-58.

7 The Tempest can be seen as a convergence of various genres.

8 An omission of Marina's forced prostitution is explainable by the perception of her as a prostitute through the prism of the early nineteenth century, when an unwritten period dictum of female respectability coupled with decorum and the domestic sphere. 


\section{Ivona Mišterová}

$9 \quad$ Vladimír Hulpach is a Czech writer, editor and screenwriter.

10 "Pravda, pirátům sice o její život samozřejmě nešlo, jenže sotva spatřili její krásu, dostali jiný, neméně zločinný nápad: prodat ji do otroctví. Až na ostrov Lesbos do města Mytiléne a s ní proto dopluli a tam ji na trhu prodali jako každou obyčejnou otrokyni. Jenže tentokrát se na Marínu konečně usmálo štěstí: sám vládce ostrova, Lysimachus, ji z otroctví vykoupil, a když po nějaké době seznal její podivuhodné příhody i královský původ, rozhodl se, že ji požádá o ruku." (Hulpach 1997: 41-42, translation author).

11 Renáta Fučíková is a Czech artist, illustrator and an author of children's books.

12 The tales are narrated by Martin Stránský, Milena Steinmasslová, Igor Bareš, Jana Stryková, Michal Balcar, Veronika Khek Kubařová and Jitka Škápíková.

13 "Neupoutává pozornost primárně k výtvarnému jazyku, nechce zahlcovat divákovy oči, ale soustředí se na sdělení, a právě proto její tvorba zdaleka překračuje běžné mantinely knižní ilustrace." (Kopáč 2019: n.p., translation author).

14 Theatre for children and young audiences (for more information, see: https:// www.i-divadlo.cz/divadlo-pro-deti, https://www.dobredivadlodetem.cz, etc.)

15 For more information, please see: http://www.divadelkoproskoly.cz/clanek/jak-jsteto-myslel-pane-shakespeare-aneb-zivot-a-dilo-nejvetsiho-dramatika-vsech-dob-

16 "Kabaretní formou odlehčujeme temné příběhy plné vražd, mystiky i tragické lásky. Kombinace kabaretu včetně autorských písniček zároveň s původními slavnými výstupy a monology ze Shakespearových tragédií tvoří dohromady nesmírně živý divadelní tvar" (Trnka 2019: n.p., translation author). For more information, see: https://www.upol.cz/nc/kalendar/akce/cal//////2479/

17 Czech puppet Shakespeare began to flourish at the beginning of the $20^{\text {th }}$ century, when Vladimír Zákrejs and Bedřich Beneš Buchlovan staged their puppet performances (Malíková 2016: n.p.).

\section{References}

Aciman, Alexander and Emmett Rensin (2009) Twitterature. The World's Greatest Books in Twenty Tweets or Less. London: Penguin.

Bezzola Lambert, Ladina and Balz Engler (eds.) (2009) Shifting the Scene: Shakespeare in European Culture. Newark: University of Delaware Press.

Carbone, Courtney and Brett Wright (2016) OMG Shakespeare. New York: Random House.

Cochran, Peter (2013) Small-Screen Shakespeare. Newcastle upon Tyne: Cambridge Scholars Publishing.

Čeporanová, Drahomíra (2014) Theatre for young audiences. In: Rubin, Don (ed.) The World Encyclopedia of Contemporary Theatre. Volume 1: Europe. Abingdon, New York: Routledge, 211.

Deary, Terry (1999) Top Ten Shakespeare Stories. New York: Scholastic.

Drábek, Pavel and M. A. Katritzky (2016) Shakespearean players in early modern Europe. Vol. 2. In: Smith, Bruce R. (gen. ed.) The Cambridge Guide to the Works of Shakespeare. Cambridge: Cambridge University Press, 1527-1533.

Educational Programme for Primary Schools (grades 1-5). Published: 30 April 1996. Available at: www.msmt.cz > file > 38765_1_1 (Accessed 19 May 2020).

Freifrau Ledebur, Ruth (2004) National identity and the teaching of Shakespeare. In: Bezzola Lambert, Ladina and Balz Engler (eds.) Shifting the Scene: Shakespeare in European Culture. Newark: University of Delaware Press, 167-181.

Fučíková, Renáta (2016) Shakespeare: 12 převyprávěných her v historických souvislostech. Praha: Vyšehrad, spol. s.r.o. 
Fučíková, Renáta (2017) Shakespeare: 12 prevyprávěných her v historických souvislostech. CD MP3 - 7 hours 31 minutes. Praha: OneHotBook.

Gibson, Rex (1998) Teaching Shakespeare: A Handbook for Teachers. Cambridge: Cambridge University Press.

Havličková Kysová, Šárka (2016) Stage metaphors in Verdi’s Otello: Miloš Wasserbauer's State Theatre production (Brno 1967) in the context of Otello's staging tradition. Theatralia 19 (2), 29-58.

Homan, Sidney (ed.) (2019) How and Why We Teach Shakespeare. London: Routledge.

Hostýnek, Tomáš (2018) Popular culture and language - Abbreviations, slang words and neologisms. Hradec Králové Journal of Anglophone Studies 5 (1), 91-100.

Hulpach, Vladimír (1996) Př́běhy ze Shakespeara I. Praha: Aventinum.

Hulpach, Vladimír (1997) Přiběhy ze Shakespeara II. Praha: Aventinum.

Kopáč, Radim. Renáta Fučíková (2019) Pořád mě to táhne do minulosti. Předni ilustrátorka vystavuje svá nejlepši díla [Renáta Fučíková. It still draws me into the past. The leading illustrator exhibits her best works]. Vltava. Výtvarné umění [Fine Arts]. Published: 21 May 2019. Available at: https:/ / vltava.rozhlas.cz/renata-fucikova-porad-me-tahne-do-minulosti-predni-ilustratorka-vystavuje-sva-7937248 (Accessed 20 May 2020).

Lamb, Charles and Mary Lamb (2013) Tales from Shakespeare. Mineola, NY: Dover Publications, Inc.

Malíková, Nina (2016) Shakespeare na českém loutkovém jevišti. Loutkář [Puppeteer] 2, 100-104. Online. Available at: http://www.loutkar.eu/index.php?h\&id=2016044 (Accessed 2 June 2020).

Miller, Naomi J. (2003) "What's in a name?”: Collaborating with Shakespeare at the millennium. In: Miller, Naomi J. (ed.) Reimagining Shakespeare for Children and Young Adults. Abingdon: Routledge, 1-10.

Mišterová, Ivona (2013a) Hamleteen: A search for identity. In: Mišterová, Ivona and Eva Skopečková, (eds.) A Search for Identity. Plzeň: Západočeská univerzita v Plzni, 44-52.

Mišterová, Ivona (2013b) Angloamerické drama na plzeňských scénách [English and American Drama on Pilsen Stages]. Plzeň: Západočeská univerzita v Plzni.

Mišterová, Ivona (2019) Shakespearean Adaptations for Young Adults. American and British Studies Annual. Pardubice: University of Pardubice, 12 (3), 44-52.

Mortimore-Smith, Shannon R. (2012) Shakespeare gets graphic: Reinventing Shakespeare through comics, graphic novels, and manga. In: Malcolm, Gabrielle and Kelli Marshall (eds.) Locating Shakespeare in the Twenty-First Century. Newcastle upon Tyne: Cambridge Scholars Publishing, 81-92.

Müller, Anja, ed. (2013) Adapting Canonical Texts in Children's Literature. London: Bloomsbury Publishing Plc.

Nesbit, Edith (1997) The Best of Shakespeare. Introduction by Iona Opie. Afterword by Peter Hunt. Oxford: Oxford University Press.

Olive, Sarah (2015) Shakespeare Valued: Education Policy and Pedagogy 1989-2009. Bristol: Intellect Ltd.

Prescott, Paul (2010) Shakespeare and popular culture. In: Margareta De Grazia and Stanley Wells (eds.) The New Cambridge Companion to Shakespeare. Cambridge: Cambridge University Press, 269-284.

Prescott, Paul (2015) Shakespeare and the dream of Olympism. In: Prescott, Paul and Erin Sullivan (eds.) Shakespeare on the Global Stage: Performance and Festivity in the Olympic Year. London: Bloomsbury Arden Shakespeare, 1-38.

Rokison-Woodall, Abigail (2013) Shakespeare for Young People: Productions, Versions and Adaptations. London: The Arden Shakespeare, Bloomsbury Publishing Plc.

Shand, G. B. (ed.) (2009) Teaching Shakespeare: Passing It On. Oxford: Blackwell Publishing Ltd. 
Shoemaker, Carrie L. (2018) Should you introduce your 5-year-old to Shakespeare? Stratford Festival Reviews. Published: 8 October 2018. Available at: https://stratfordfestivalreviews.com/blog/2018/10/08/should-you-introduce-your-5-year-old-to-shakespeare/ (Accessed 26 March 2020).

Soprová, Jana (2005) Macbeth v Divadle Lampion [Macbeth at the Lampoon Theatre]. Scéna.cz. 1 Kulturní portál. Published: 14 February 2005. Available at: http://www.scena.

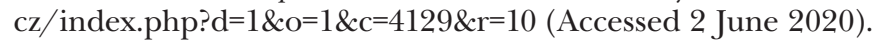

The Royal Shakespeare Company. Education. Available at: https://www.rsc.org.uk/education/ (Accessed 30 March 2020).

Thompson, Ayanna and Laura Turchi (2016) Teaching Shakespeare with Purpose: A Student-Centred Approach. London: Bloomsbury Publishing Plc.

Trnka, Jiří (2019) Kabaret Nahatý Shakespeare [Cabaret the Naked Shakespeare] Palacky University Olomouc. Published: 9 August 2019. Available at: https://www.upol.cz/nc/ en/calendar/event/cal//////2479/ (Accessed 19 May 2020).

Williams, Marcia (2009) Bravo, Mr William Shakespeare! London: Walker Books.

Winston, Joe (2015) Transforming the Teaching of Shakespeare with the Royal Shakespeare Company. London: Bloomsbury Publishing Plc.

Ivona MišTerová is a senior lecturer at the Department of English Language and Literature at the University of West Bohemia in Pilsen, Czech Republic. She received her Ph.D. in English and American Literature from Charles University in Prague. Ivona has published monographs on performances of British and American works staged in Czech theatres in the 20th and 21st centuries (Anglo-americké drama na plzeňských scénách [Anglo-American Drama on Pilsen Stages, 2013], and Inter Arma non Silent Musae. Anglická a americká tvorba na českých moravských divadelnich scénách v době prvni světové války [Inter Arma non Silent Musae. English and American Drama on Czech and Moravian Stages during the Great War, 2017]).

Address: PhDr. Ivona Mišterová, Ph.D., Department of English Language and Literature, Faculty of Arts and Philosophy, University of West Bohemia in Pilsen, Sedláčkova 15, 306 14 Pilsen, Czech Republic. [email: yvonne@kaj.zcu.cz] 